\title{
Evaluation of Age-Dependent Immune Signatures in Patients With Multiple Sclerosis
}

Melanie Eschborn, PhD,* Marc Pawlitzki, MD, * Timo Wirth, PhD,* Christopher Nelke, MD, Steffen Pfeuffer, MD, Andreas Schulte-Mecklenbeck, PhD, Lisa Lohmann, MD, Leoni Rolfes, MD, Katrin Pape, MD, Maria Eveslage, MSc, Stefan Bittner, MD, Catharina C. Gross, PhD, Tobias Ruck, MD, Heinz Wiendl, MD, Sven G. Meuth, MD, PhD, $†$ and Luisa Klotz, MD $\dagger$

Neurol Neuroimmunol Neuroinflamm 2021;8:e1094. doi:10.1212/NXI.0000000000001094

\section{Abstract}

\section{Background and Objectives}

In MS, an age-related decline in disease activity and a decreased efficacy of disease-modifying treatment have been linked to immunosenescence, a state of cellular dysfunction associated with chronic inflammation.

\section{Methods}

To evaluate age-related immunologic alterations in MS, we compared immune signatures in peripheral blood $(\mathrm{PB})$ and CSF by flow cytometry in patients with relapsing-remitting (RR) $(\mathrm{PB} \mathrm{n}=38$; $\mathrm{CSF} \mathrm{n}=51)$ and primary progressive $(\mathrm{PP}) \mathrm{MS}(\mathrm{PB} \mathrm{n}=40 ; \operatorname{CSF} \mathrm{n}=36)$ and respective controls $(\mathrm{PB} \mathrm{n}=40$; $\mathrm{CSF} \mathrm{n}=85)$.

\section{Results}

Analysis revealed significant age-related changes in blood immune cell composition, especially in the CD8 T-cell compartment of healthy donors (HDs) and patients with MS. However, HDs displayed a strong age-dependent decline in the expression of the immunoregulatory molecules KLRG1, LAG3, and CTLA-4 on memory CD8 T cells, whereas this age-dependent reduction was completely abrogated in patients with MS. An age-dependent increase in the expression of the costimulatory molecule CD226 on memory CD $8 \mathrm{~T}$ cells was absent in patients with MS. CD226 expression correlated with disability in younger ( $\leq 50$ years) patients with MS. CSF analysis revealed a significant age-dependent decline in various immune cell populations in PPMS but not RRMS, suggesting a differential effect of aging on the intrathecal compartment in PPMS.

\section{Discussion}

Our data illustrate that aging in MS is associated with a dysbalance between costimulatory and immunoregulatory signals provided by $\mathrm{CD} 8 \mathrm{~T}$ cells favoring a proinflammatory phenotype and, more importantly, a pattern of premature immune aging in the CD8 T-cell compartment of young patients with MS with potential implications for disease severity.

\author{
Correspondence \\ Dr. Klotz \\ luisa.klotz@ukmuenster.de
}




\section{Glossary}

CM = central memory; CTLA-4 = cytotoxic T lymphocyte-associated protein 4; DMT = disease-modifying therapy; DNAM$\mathbf{1}=$ DNAX accessory molecule-1; EAE = experimental autoimmune encephalomyelitis; EDSS = Expanded Disability Status Scale; EM = effector memory; HD = healthy donor; IFN- $\gamma=$ interferon-gamma; KLRG1 = killer cell lectin-like receptor subfamily G member 1; LAG3 = lymphocyte-activation gene 3; MFI = mean fluorescence intensity; MS = multiple sclerosis; NIC = noninflammatory control; NK = natural killer; $\mathbf{P B}=$ peripheral blood; $\mathbf{P B M C}=$ peripheral blood mononuclear cell; PPMS = primary progressive multiple sclerosis; RA = rheumatoid arthritis; RRMS = relapsing-remitting multiple sclerosis; $\mathbf{s N f L}=$ serum neurofilament light chain; SLE $=$ systemic lupus erythematosus; TNF- $\alpha=$ tumor necrosis factor alpha.

Because of the increased longevity of the general population worldwide, the concept of immunosenescence is drawing increased attention. Immunosenescence describes the gradual decline of immune system functions with age. ${ }^{1}$ Functional consequences of immunosenescence comprise a reduced adaptive immune response to vaccinations and an enhanced susceptibility to infections and for the development of distinct autoimmune diseases in elderly individuals. ${ }^{1,2}$

Aging represents a great challenge in clinical management of multiple sclerosis (MS) as the proportion of patients with a long-term relapsing-remitting MS (RRMS) disease course at an age of around 50 years is increasing. ${ }^{3}$ To date, there is a wide range of immunotherapy options for patients with RRMS. Nevertheless, a large part of clinical trials did not include patients with RRMS over approximately 50 years of age, which implies that the safety and efficacy of these drugs have not been systematically evaluated in this particular population. ${ }^{3}$ A metaanalysis of clinical data from patients with RRMS demonstrated that the efficacy of disease-modifying therapies (DMTs) is substantially decreased with age. ${ }^{4}$ At the same time, the risk of severe adverse events under DMTs increases in patients with RRMS older than 50 years. ${ }^{5,6}$ The majority of approved treatment approaches for RRMS fail to demonstrate the efficacy in patients with progressive MS usually diagnosed at an age above $50-55$ years. ${ }^{3,7}$ These findings indicate that different types of MS exhibit distinct pathophysiologic mechanisms that might appear in an age-dependent manner.

An accelerated aging process has already been implicated in other autoimmune diseases such as systemic lupus erythematosus (SLE) and rheumatoid arthritis (RA). ${ }^{9-11}$ In autoimmunity, chronic inflammation drives cells into senescence, which results in a decreased ability for tissue repair and thus contributes to the disease pathogenesis (e.g., as in RA).,12 The accumulation of $\mathrm{CD} 4^{+} \mathrm{CD} 28^{-} \mathrm{T}$ cells in the peripheral blood (PB), a hallmark of senescence, might contribute to disease progression in patients with $\mathrm{RA}^{10,11,13-15}$ The expansion of senescent $\mathrm{CD} 4^{+} \mathrm{CD} 28^{-}$ $\mathrm{T}$ cells has been found in CNS lesions and PB of patients with MS supporting a crucial role for immunosenescence in MS as well. ${ }^{13,14,16}$ Cellular senescence might also interfere with recovery in MS, as senescence in neural precursor cells impairs remyelination in CNS lesions of patients with primary progressive MS (PPMS). ${ }^{17}$ However, comprehensive studies investigating immunosenescence in peripheral immune signatures of RRMS vs
PPMS in young vs old individuals are still lacking. The aim of the present study is to investigate the effect of aging on immune signatures of age- and sex-matched patients with RRMS and PPMS in comparison to controls in peripheral and intrathecal compartments. We hypothesize that patients with MS might display signs of accelerated immune aging, which could affect disease progression. To evaluate the underlying pathophysiologic differences of patients and controls during aging, we studied the immune profile with respect to senescence markers and additional relevant immunologic markers by multicolor flow cytometry.

\section{Methods}

\section{Study Design}

The study comprised 2 independent cohorts (A: peripheral blood mononuclear cell [PBMC] cohort; B: CSF cohort). Demographic data are shown in eTables 1 and 2, links.lww. com/NXI/A620 and links.lww.com/NXI/A621. Cohort A included age- and sex-matched patients with RRMS $(n=38)$ and PPMS $(n=40)$ according to the McDonald criteria revised in $2017^{18}$ and healthy donors (HDs) $(n=40)$ who underwent comprehensive immunophenotyping in $\mathrm{PB}$. Cohort B consisted of patients with RRMS ( $n=51)$, patients with PPMS ( $n=36)$, and noninflammatory controls (NICs) $(n=85)$ who underwent comprehensive immunophenotyping in CSF. NICs comprised patients with somatoform disorders or patients who donated CSF during the course of spinal anesthesia as described previously. ${ }^{19}$ Groups in each cohort were subdivided into young ( $\leq 50$ years) and old $(>50$ years) participants. One rationale behind the 50 -year cutoff is that the DMT efficacy for RRMS has mostly been tested only in clinical trials with patients up to $50-55$ years ${ }^{3,4}$ Furthermore, a recent meta-analysis shows that there is a lower efficacy of DMTs for the average of patients with MS beyond 53 years. ${ }^{4}$ Another aspect for choosing this distinct cutoff is that the median age of our main study cohort A is 50 years. As validation, key immunologic markers are also presented as correlation with age.

For the composition of the study cohort, the following exclusion criteria were fulfilled:

- Patients with a chronic disease of the immune system in addition to MS who requires long-term immunotherapy or is associated with a known immunodeficiency 
A. Lymphocytes

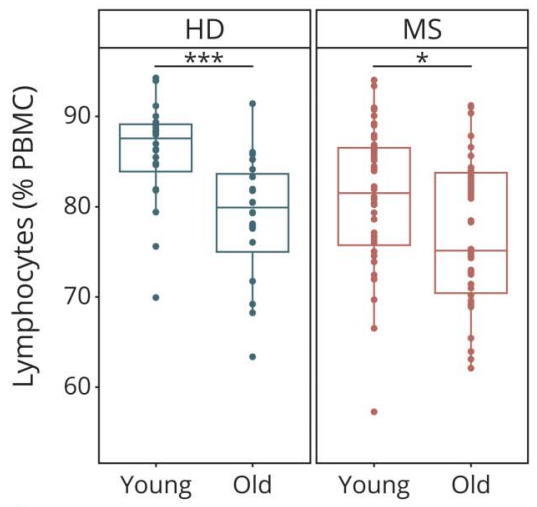

C. CD4 T cells

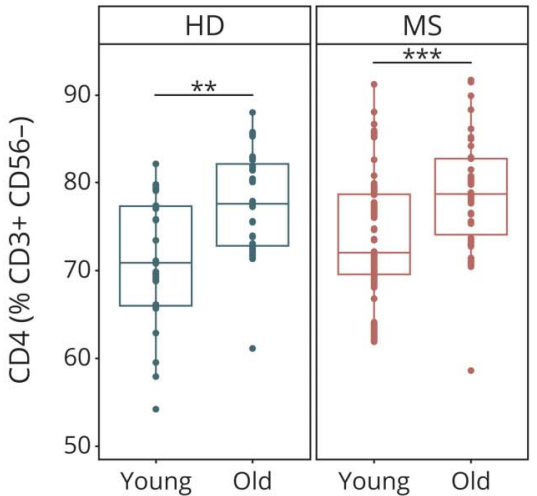

B. B cells

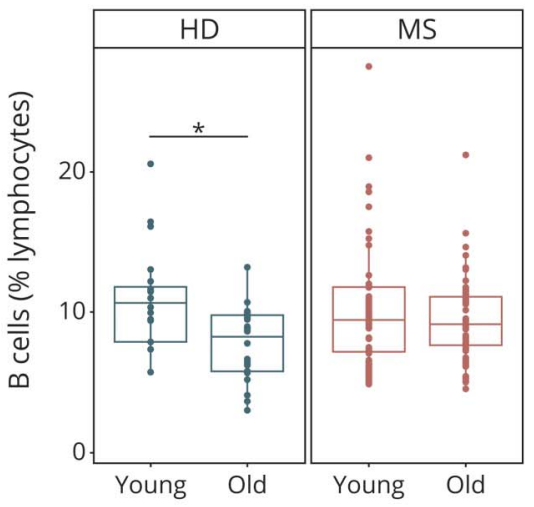

D. CD8 T cells

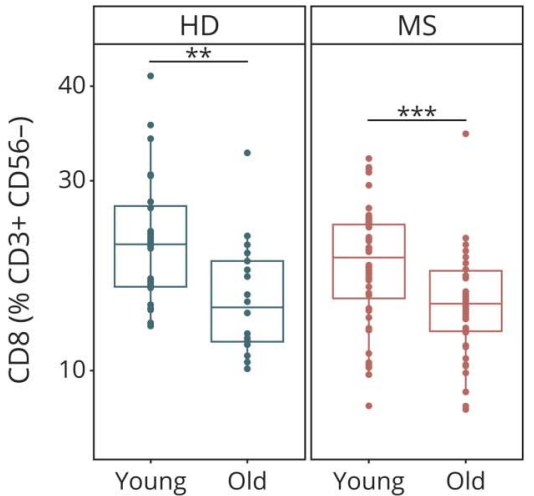

Immune cell subset composition in the peripheral blood of young ( $\leq 50$ years) and old (>50 years) patients with multiple sclerosis (MS) (young: $n=$ 40 , old: $n=38$ ) and HDs (young: $n=20$, old: $n=20$ ). Demographic data of study subjects are depicted in eTable 1 (A-D, links.Iww.com/NXI/A620). Frequencies of lymphocytes (A), B cells (B), CD4 (C), and CD 8 (D) T cells. Data are displayed as boxplots of the median and the 25th and 75th percentile \pm interquartile range. Statistical analysis was conducted by the 2-tailed Mann-Whitney test. Differences were considered statistically significant with the following $p$ values: ${ }^{\star} p<0.05, * \star p<0.01$, and $* * * p<0.001$. HD $=$ healthy donor
- Patients with RRMS who presented with an acute clinical relapse within the preceding 6 weeks

- Patients with RRMS and PPMS who presented an enhanced T2 lesion load or a gadolinium-enhanced cerebral or spinal cord T1-weighted lesions in an MRI scan, which was performed no longer than 1 month ago

- Patients who received ongoing immunotherapy

- Patients with RRMS with the following treatment history:

- IV cortisone pulse therapy within 3 months before inclusion

- Interferon-beta, glatiramer acetate, teriflunomide, or dimethyl fumarate within 2 years before inclusion

- Fingolimod or natalizumab within 6 months before inclusion

- Previous treatment with ocrelizumab, rituximab, alemtuzumab, or cladribine

- Patients with PPMS with the following treatment history:

- IV cortisone pulse therapy within 3 months of inclusion

- Mitoxantrone within 12 months before inclusion

- Previous treatment with ocrelizumab or rituximab

- Other immunomodulatory therapies within 3 months before inclusion

Because this was a proof-of-concept study, pilot group size was used. As possible confounders such as sex, disease duration,
Expanded Disability Status Scale (EDSS), and MRI lesion load might impair the read out, we adjusted data from patients with MS of our main PBMC cohort for these covariates (eFigure 1, links. lww.com/NXI/A607; eTable 3, links.lww.com/NXI/A622).

Sampling and Flow Cytometric Analysis of PBMCs Whole-blood samples were collected from study subjects. PBMCs were isolated by Ficoll (Sigma-Aldrich) density gradient centrifugation and stored in liquid nitrogen according to our standard operating procedure. ${ }^{20}$ Freshly thawed or stimulated PBMCs were stained with fluorochromeconjugated antibodies. For further information, please see eMethods, links.lww.com/NXI/A626.

\section{Data Analysis}

For data analysis, we used Kaluza Flow Cytometry Analysis software version 2.1. We used scripts generated in $\mathrm{R}$ version 4.0.2 ("Taking Off Again") 21 and RStudio version 1.3.959 for streamlined batch generation of box plots and age correlation plots.

\section{Statistical Analysis}

For continuous variables, the independent-sample $t$ test or Mann-Whitney $U$ test and analysis of variance with post hoc Bonferroni testing were conducted as appropriate. To assess 
A. CD8 naive

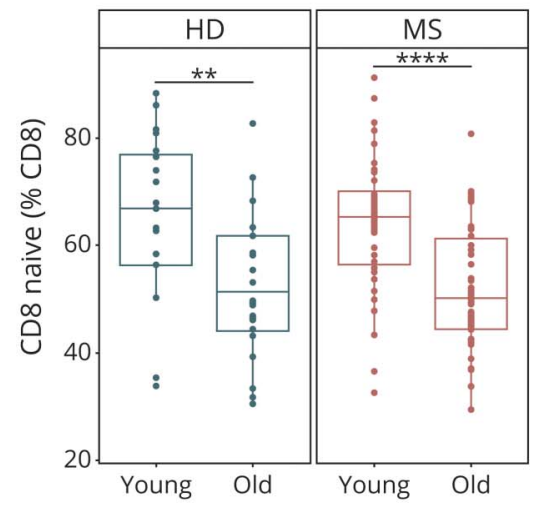

C. CD8 EM

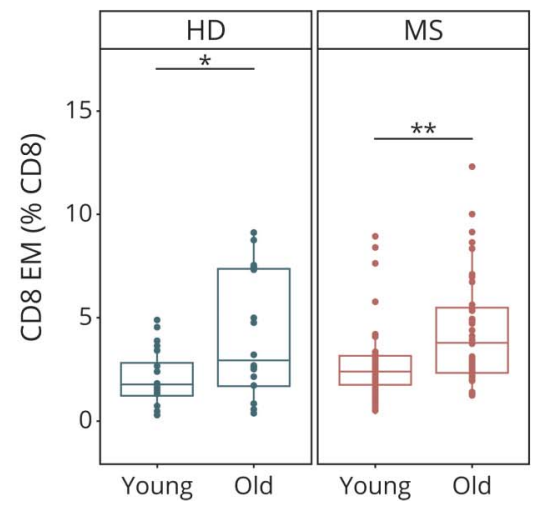

B. CD8 memory

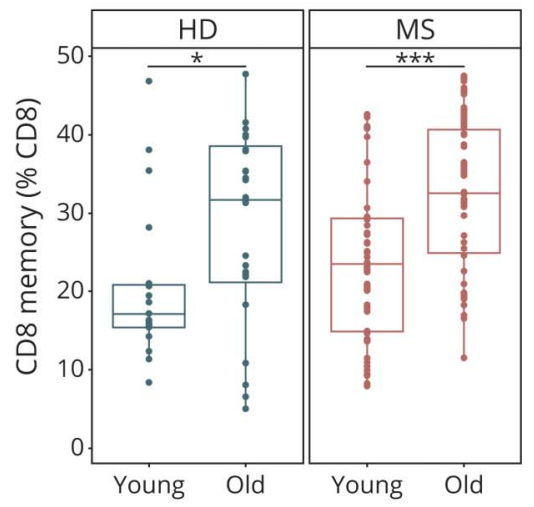

D. CD8 CM

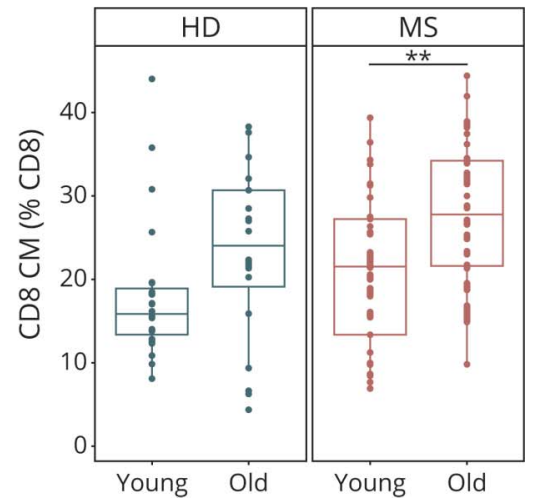

Composition of the CD8 T-cell compartment in the peripheral blood of young ( $\leq 50$ years) and old $(>50$ years) patients with MS (young: $n=40$, old: $n=38$ ) and HDs (young: $n=20$, old: $n=20$ ). Demographic data of study subjects are depicted in eTable 1 (A-D, links.Iww.com/NXI/A620). Proportions of naive (A), memory (B), effector memory (C), and central memory (D) CD8 T cells. Data are displayed as boxplots of the median and the 25th and 75th percentile \pm interquartile range. Statistical analysis was conducted by the 2-tailed Mann-Whitney test. Differences were considered statistically significant with the following $P$ values: ${ }^{*} p<0.05, * * p<0.01$, $* * * p<0.001$, and $* * * * p<0.0001$. CM = central memory; $\mathrm{EM}=$ effector memory; $\mathrm{HD}=$ healthy donor. the relationship between age and immune parameters, we computed Pearson product-moment correlation coefficients (Pearson R). To adjust for possible confounders, we used median regression ( $\mathrm{R}$ package quantreg) including age, sex, disease duration, EDSS, and lesion load as covariates. Differences were considered statistically significant with the following $p$ values: ${ }^{*} p<0.05,{ }^{* *} p<0.01,{ }^{* * *} p<0.001$, and ${ }^{* * * *} p<$ 0.0001 . Nevertheless, all analyses should be considered as exploratory. If possible, investigators were blinded throughout data acquisition and analysis. Clinical scoring was independent of flow cytometric analysis.

\section{Standard Protocol Approvals, Registrations, and Patient Consents}

The local ethics committee (2016-053-f-S) approved blood and CSF sampling, and all subjects provided written informed consent before entering the study. This trial was conducted in accordance with the Declaration of Helsinki.

\section{Data Availability}

All data associated with this study are present in the article or the supplementary material. Data and codes of all scripts are available from the corresponding author on reasonable request. All models were created using publicly available packages and functions in the $\mathrm{R}$ programming language. For further information, please see eMethods (links.lww.com/NXI/A626).

\section{Results}

\section{Age-Dependent Alterations in Peripheral Immune Cell Composition in MS}

We investigated potential age-related changes in peripheral immune signatures by multiparameter flow cytometry using a cohort of age- and sex-matched patients with RRMS $(n=38)$ and PPMS $(n=40)$ and HDs $(n=40)$ (young $\leq 50$ years; old $>50$ years). None of the patients received any DMT for at least 3 months before blood sampling. Demographic data and key information of clinical characteristics are depicted in eTable 1, links.lww.com/NXI/A620.

In accordance to the literature, ${ }^{22,23}$ characterization of major immune cell populations revealed an age-dependent decrease in the proportions of lymphocytes, B cells and CD8 $\mathrm{T}$ cells with a concomitant increase in CD4 T cells in HDs (Figure 1, eFigure 2, links.lww.com/NXI/A608). In patients with MS, these agedependent alterations were less pronounced albeit still significant, at least for lymphocytes, CD4 and CD8 T cells (Figure 1, eFigure 2, links.lww.com/NXI/A608). The CD8 T-cell compartment exhibited a particularly strong age dependency in controls and in patients with MS, with a decrease in naive CD8 T cells and a reciprocal increase in $\mathrm{CD} 8$ memory $\mathrm{T}$ cells reflecting an increase in effector and central memory (EM and CM) subsets (Figure 2, eFigure 3, links.lww.com/NXI/A609). Direct comparison of 
A. CD8 memory KLRG1

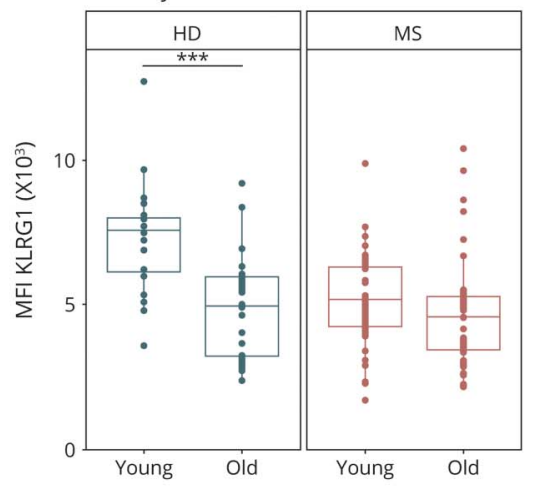

C. CD8 memory LAG3

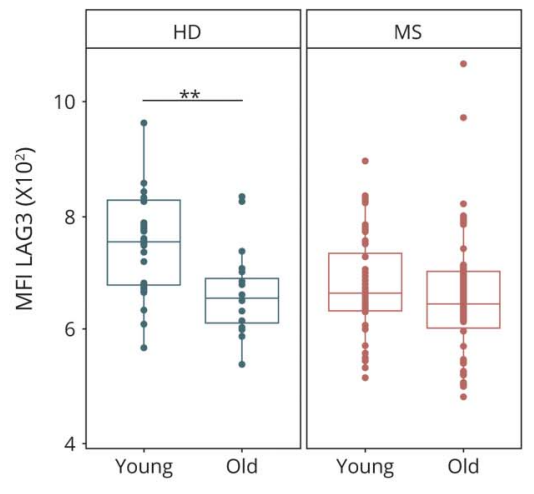

B

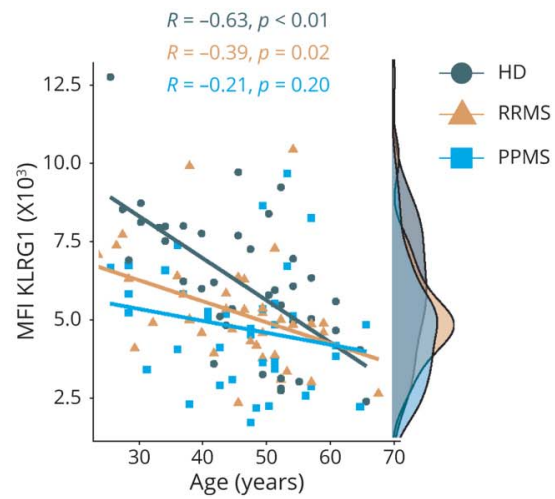

$\mathrm{D}$

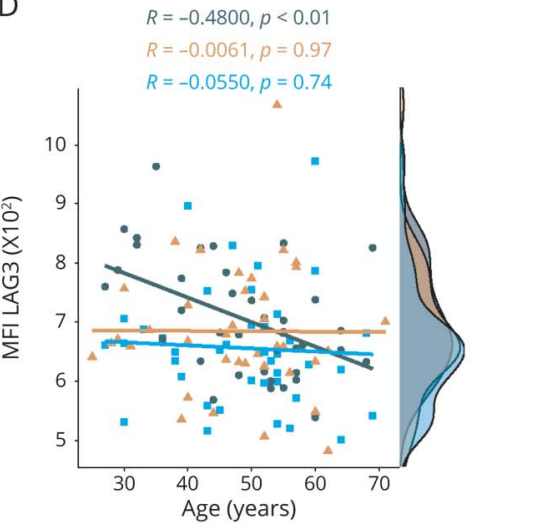

Flow cytometric analysis of frozen peripheral blood mononuclear cells from young ( $\leq 50$ years) and old ( $>50$ years) patients with MS (MS: young: $n$ =40, old: $n=38$; RRMS: young: $n=20$, old: $n=18$; PPMS: young: $n=20$, old: $n=20$ ) and HDs (young: $n$ $=20$, old: $n=20$ ). Demographic data of study subjects are depicted in eTable 1, links.Iww.com/NXI/ A620. (A) MFI of KLRG1 on memory CD8 T cells of patients with MS and HDs. (B) Correlation analysis of MFI of KLRG1 on memory CD8 T cells with age of HDs $(n=40)$, patients with RRMS $(n=38)$, and patients with PPMS $(n=40)$. (C) MFI of LAG3 on memory CD8 T cells of patients with MS and HDs. (D) Correlation analysis of MFI of LAG3 on memory CD8 T cells with age of HDs $(n=40)$, patients with RRMS $(n=38)$, and patients with PPMS $(n=40)$. Data are displayed as boxplots of the median and the 25th and 75th percentile \pm interquartile range. Statistical analysis was conducted by the 2-tailed Mann-Whitney test. For correlation analysis, the Pearson product-moment correlation coefficients (Pearson R) were computed. Differences were considered statistically significant with the following $p$ values: ${ }^{*} p<0.01$ and $* \star \star x p<0.001$. $\mathrm{HD}=$ healthy donor; $\mathrm{KLRG1}=$ killer cell lectin-like receptor subfamily G member 1; LAG3 = lymphocyte-activation gene $3 ; \mathrm{MFI}=$ mean fluorescence intensity; MS = multiple sclerosis; PPMS = primary progressive MS; RRMS = relapsing-remitting MS. patients with RRMS and PPMS revealed that age-dependent changes within the CD8 T-cell compartment were more pronounced in patients with PPMS compared with patients with RRMS (eFigure 3B, links.lww.com/NXI/A609). CD4 T-cell subsets did not exhibit pronounced age-dependent alterations, neither in controls nor in patients with MS (eFigure 4, links.lww. com/NXI/A610). Overall, these data reveal strong age-related alterations within the lymphocyte compartment of HDs and patients with MS, which are particularly pronounced in the CD8 T-cell compartment.

\section{Features of Premature Immune Aging in Young Patients With MS}

Next, we evaluated age-dependent changes in immunoregulatory and immunosenescence-related molecules within the T-cell compartment (eTable 4, links.lww.com/NXI/A623). Notably, we observed an age-related increase in $\mathrm{CD} 4^{+} \mathrm{CD} 28^{-}$ $\mathrm{T}$ cells in HDs and patients with MS (eFigure 5A, links.lww. com/NXI/A611). Nevertheless, we did not detect agedependent changes in frequencies of $\mathrm{CD}^{+} \mathrm{CD} 28^{-} \mathrm{T}$ cells and $\mathrm{CD}^{+} 7^{+} \mathrm{T}$ cells neither in controls nor in patients with MS (eFigure 5, links.lww.com/NXI/A623). We did notice a strong age-dependent decrease in the expression of several immunoinhibitory molecules such as killer cell lectin-like receptor subfamily G member 1 (KLRG1), lymphocyteactivation gene 3 (LAG3), and cytotoxic T lymphocyte- associated protein 4 (CTLA-4) on memory CD8 $\mathrm{T}$ cells and respective subsets from $\mathrm{HDs}$ (Figure 3, eFigure 6, links.lww. com/NXI/A612). Importantly, this age-dependent regulation was abrogated in patients with MS, as young patients already exhibited expression levels of these molecules comparable to those from old patients with MS or old HDs (Figure 3, eFigure 6, links.lww.com/NXI/A612). Direct comparison of patients with RRMS and PPMS revealed that this loss of agedependent regulation was slightly more pronounced in patients with PPMS compared with patients with RRMS (Figure 3, B and D, eFigure 6, links.lww.com/NXI/A612). With regard to functional properties of $\mathrm{T}$ cells, we showed that CD8 T cells of elderly had an increased expression of CD107a, a marker for degranulation of cytolytic vesicles on $\mathrm{T}$ cell receptor stimulation (eFigure 7A, links.lww.com/NXI/ A613). T cells of old patients with MS displayed significantly increased intracellular expression of interferon-gamma (IFN$\gamma$ ) and tumor necrosis factor alpha (TNF- $\alpha$ ) on stimulation, which was less pronounced in the $\mathrm{HD}$ cohort (eFigure 7, B-D, links.lww.com/NXI/A613). Of note, HDs exhibited a strong age-dependent increase in the costimulatory molecule CD226 (DNAX accessory molecule-1, DNAM-1) on memory and EM CD8 T cells (Figure 4, eFigure 8, links.lww.com/ NXI/A614). Again, this age-dependent modulation was much less pronounced in patients with MS, in particular in patients with PPMS, due to elevated levels already in the young MS 

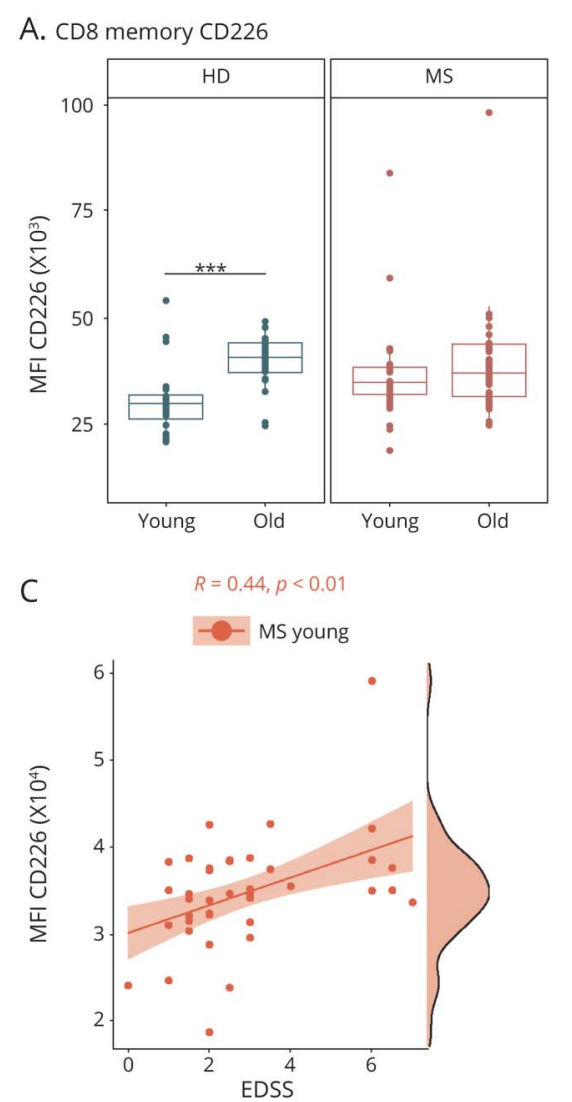
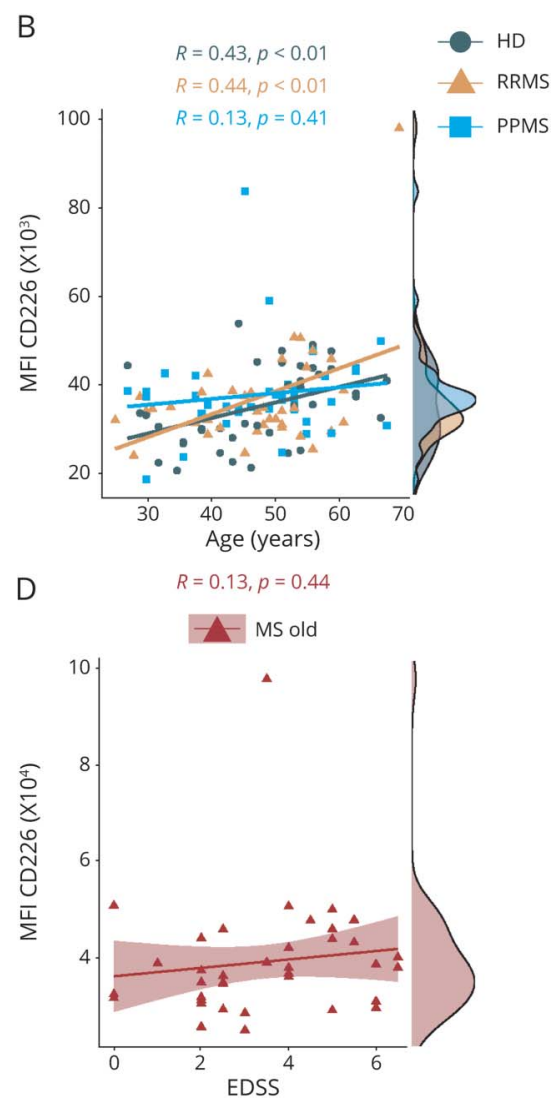

Flow cytometric analysis of frozen peripheral blood mononuclear cells from young ( $\leq 50$ years) and old ( $>50$ years) patients with MS (MS: young: $n$ $=40$, old: $n=38$; RRMS: young: $n=20$, old: $n=18$; PPMS: young: $n=20$, old: $n=20$ ) and HDs (young: $n$ $=20$, old: $n=20$ ). Demographic data of study subjects are depicted in eTable 1, links.lww.com/NXI/ A620. (A) MFI of CD226 (DNAM-1) on memory CD8 $\mathrm{T}$ cells. (B) Correlation analysis of MFI of CD226 on memory CD8 T cells with age of HDs $(n=40)$, patients with RRMS $(n=38)$, and patients with PPMS ( $n$ $=40)$. (C, D) Correlation analysis of CD226 expression on memory CD8 T cells with the EDSS score of young (C) and old (D) patients with MS. Data are displayed as boxplots of the median and the 25th and 75 th percentile \pm interquartile range. Statistical analysis was conducted by the 2-tailed MannWhitney test. For correlation analysis, the Pearson product-moment correlation coefficients (Pearson R) were computed. Differences were considered statistically significant with the following $p$ values: $\star \star p<0.01$ and $* * \star p<0.001$. EDSS = Expanded Disability Status Scale; HD = healthy donor; MS = multiple sclerosis; $\mathrm{MFI}=$ mean fluorescence intensity; PPMS = primary progressive MS; RRMS = relapsing-remitting $\mathrm{MS}$. population (Figure 4B, eFigure 8A, links.lww.com/NXI/A614). Notably, for CD226 expression on memory and EM CD8 $\mathrm{T}$ cells, we observed a significant correlation with disability as reflected by the EDSS in young but not in old patients (Figure 4, $\mathrm{C}$ and $\mathrm{D}$, eFigure 8B, links.lww.com/NXI/A614). In a similar line of evidence, we observed a distinct correlation between serum neurofilament light chain ( $\mathrm{sNfL}$ ) levels and the presence of senescence-associated T-cell traits, i.e., CD28 negativity and CD57 and KLRG1 expression specifically in young but not old patients with MS (eFigure 9, links.lww.com/NXI/A615), possibly suggesting a link between the loss of age-dependent regulation and clinical disease manifestation. In a subgroup analysis of only treatment-naive patients with MS, we could confirm those premature immune aging signatures of KLRG1, LAG3, CTLA-4, and CD226 in young patients with MS (eFigure 10, links.lww. com/NXI/A616). When we divided our study cohort into tertiles by age, the premature immune aging signatures in the CD8 memory compartment were also evident (eFigure 11, links.lww. com/NXI/A617).

\section{Age-Dependent Alterations of Immune Cell Subsets in the CSF}

In an additional independent cohort, we evaluated potential age-dependent alterations in immune cell composition and activation status in the CSF of 51 patients with RRMS and 36 patients with PPMS and 85 NICs by multiparameter flow cytometry. Demographic data and key information of clinical characteristics are depicted in eTable 2, links.lww.com/NXI/ A621. In patients with RRMS, lumbar puncture was performed at least 6 weeks after the last acute clinical disease activity to avoid potential relapse-associated alterations in CSF subset composition. Notably, in controls, we did not observe any agedependent alteration in total cell numbers of major immune cell populations as well as human leukocyte antigen-DR expressing T cells (Figure 5, eFigure 12, links.lww.com/NXI/ A618). In contrast, we observed an age-dependent decrease in counts of lymphocytes, B and T cells, as well as plasma cells and natural killer (NK) cells in patients with PPMS but not in patients with RRMS (Figure 5, eFigure 12, links.lww.com/ NXI/A618), suggesting an age-dependent decrease in immune cell infiltration into the CSF in the context of PPMS.

\section{Discussion}

Our study provides a comprehensive overview of age-related changes in peripheral immune signatures of patients with RRMS and PPMS compared with controls. We reveal that especially the CD8 T-cell compartment of young patients with MS exhibits signs of premature immune aging.

In accordance to the literature, ${ }^{22,23}$ we could verify that elderly HDs and patients with MS exhibit decreased proportions 
A. Lymphocytes

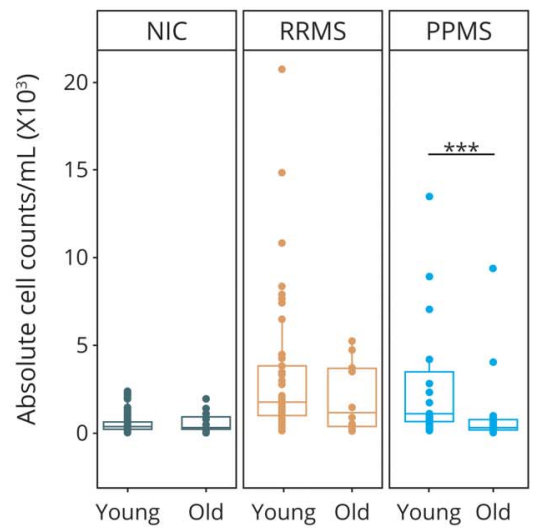

C. $T$ cells

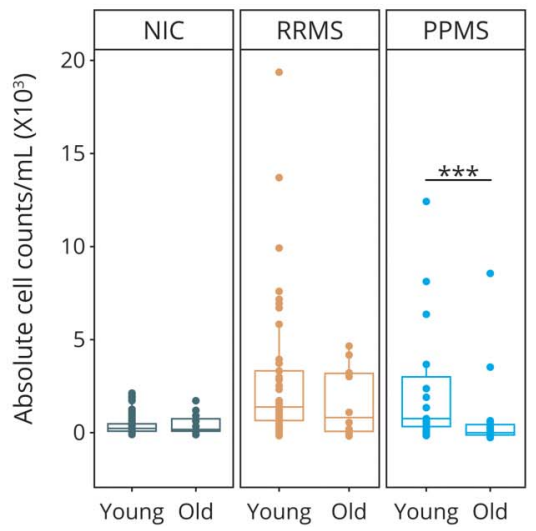

B. B cells

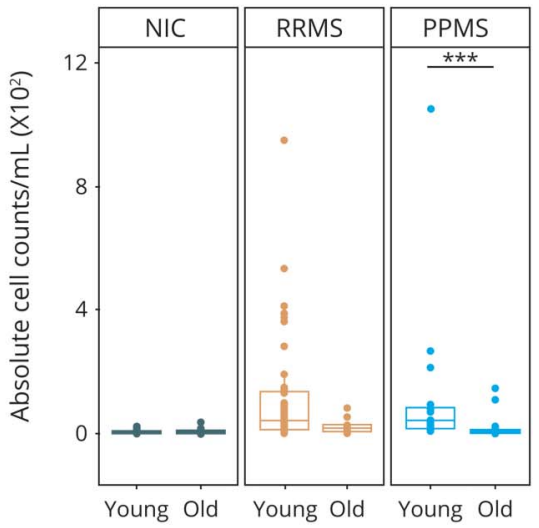

D. Plasma cells

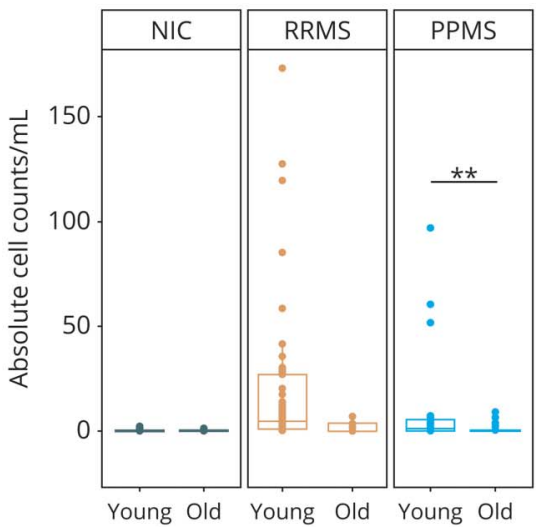

Immune cell subset composition in the in the CSF of young ( $\leq 50$ years) and old ( $>50$ years) NICs (young $n$ $=60$; old: $n=25$ ) and patients with RRMS (young: $n=$ 41; old: $n=10$ ) and PPMS (young: $n=15$; old: $n=21$ ). Demographic data of study subjects are depicted in eTable 2, links.Iww.com/NXI/A621. (A-D) Absolute numbers of lymphocytes (A), B cells (B), T cells (C), and plasma cells (D). Data are displayed as boxplots of the median and the 25th and 75th percentile \pm interquartile range. Statistical analysis was conducted by the 2-tailed Mann-Whitney test. Differences were considered statistically significant with the following $p$-values: $* * p<0.01$ and ${ }^{* *} p<0.001$. $\mathrm{NIC}=$ noninflammatory control; PPMS = primary progressive MS; RRMS = relapsing-remitting MS. of lymphocytes and CD8 T cells with a concomitant increase in CD4 T-cell proportions. Particularly, the composition of the CD8 T-cell compartment shifts toward a higher proportion of memory $\mathrm{T}$ cells in the elderly, whereas the naive $\mathrm{T}$-cell frequency decreases in the $\mathrm{PB}$ of HDs, as described previously. $^{24,25}$ Decreasing lymphocyte and naive T-cell proportions across the lifespan are driven by thymic involution and decreased hematopoietic output by the bone marrow of aged individuals. ${ }^{26}$ Although we showed that CD4 $\mathrm{T}$-cell frequencies correlate with age, the composition of the CD4 T-cell compartment is less impaired in aging compared with the CD8 T-cell compartment. ${ }^{24,27}$

Of interest, we observed elevated proportions of senescenceassociated $\mathrm{CD}^{+} \mathrm{CD} 28^{-} \mathrm{T}$ cells in the periphery of older $\mathrm{HDs}$ and patients with MS, whereas we found no increase in $\mathrm{CD}^{+} \mathrm{CD} 28^{-}$T cells. $^{15,23,28}$ The finding of elevated $\mathrm{CD} 4^{+} \mathrm{CD} 28^{-}$ $\mathrm{T}$-cell proportions is in line with other human studies that showed a relative increase of $\mathrm{CD} 4^{+} \mathrm{CD} 28^{-} \mathrm{T}$ cells with age in the periphery of patients with MS and patients with other autoimmune diseases such as RA and SLE. ${ }^{14,28,29} \mathrm{CD} 4^{+} \mathrm{CD} 28^{-} \mathrm{T}$ cells in brain lesions of patients with MS have been identified to exhibit pathogenic properties contributing to tissue damage. ${ }^{16,28}$ Of interest, we did not detect an increase in the expression of another prominent senescence marker CD57 on $\mathrm{T}$ cells of elderly subjects. $^{30}$

In our study, we aimed to focus on a comprehensive characterization of age-dependent changes of immunoregulatory molecules in age- and sex-matched as well as untreated patients with RRMS and PPMS. We observed that the CD8 T-cell compartment of young patients with MS displayed signs of premature immune aging, as young patients with MS displayed alterations in immunoregulatory and costimulatory molecules that were comparable to those observed in elderly HDs. Especially, the comprised decrease in the levels of the coinhibitory markers KLRG1 and LAG3 and the concomitant increase of the costimulatory molecule CD226 were even more pronounced in young patients with PPMS compared with patients with RRMS, pointing toward an accelerated aging process in patients with progressive MS. Similar to the HDs in our study, aged patients with MS showed a pronounced relative increase of the nonclassical $\left(\mathrm{CD} 14^{+-}\right.$ CD16 ${ }^{\text {high }}$ ) monocyte subset (eFigure 13A and B, links.lww. com/NXI/A619). However, different to the T-cell compartment, we only detected age-related changes but no indicators for a premature aging process in MS in the monocyte compartment (eFigure 13, links.lww.com/NXI/A619). 
In contrast to what has been suggested in the literature regarding senescence and autoimmunity, ${ }^{3,31}$ we did not find evidence of enhanced age-dependent alterations of immune signatures in elderly patients with MS compared with controls, at least not by our multiparameter flow cytometry approach. Instead, we observed that overall, the immune signatures of HDs and patients with MS rather similarly correlated with age. Therefore, our data do not support the idea, as proposed by a meta-analysis ${ }^{4}$ that elderly patients with MS should exhibit enhanced or accelerated immune aging, which had been conceptionally linked to the observed reduced response to immunomodulatory treatment in older patients with MS. In addition, our data underpin recent clinical observations that MS-related autoimmunity might not lead to a significantly increased risk of severe infectious diseases like COVID-19. It rather seems that besides age, the extent of disability and a higher degree of immunosuppression in patients with MS might drive COVID-19 susceptibility. ${ }^{32}$ Of interest, we observed that $\mathrm{T}$ cells from older controls and patients with MS exhibit an elevated degranulation of cytolytic vesicles and display an age-related increase in the production of IFN- $\gamma$ and TNF- $\alpha$, pointing toward a proinflammatory phenotype in aging. Based on our setup, we cannot exclude that antigen-specific immune responses, e.g., against viruses, might be impaired in the elderly population, as these more complex immune functions are not properly mirrored by our flow cytometry analysis approach. Overall, our data support the notion of an enhanced proinflammatory state of $\mathrm{T}$ cells in elderly individuals rather than an impaired immune function in this population.

Based on our data, we can conclude that the CD8 T-cell compartment of younger patients with MS is pathophysiologically distinct to the one of age-matched HDs. However, whether these signs of premature aging are a cause or consequence of the inflammatory activity in MS cannot be revealed from our data. Notably, these changes were more pronounced in patients with PPMS than in patients with RRMS. This finding was somewhat surprising in light of the fact that in clinical practice, the majority of immunotherapies used in patients with RRMS are not effective in patients with PPMS. ${ }^{7,8}$ It has been suggested that this might be due to a relatively low inflammatory vs neurodegenerative component within the pathophysiologic trajectories of PPMS. ${ }^{3,33}$ However, our data rather suggest that also PPMS is characterized by a distinct proinflammatory component, which might be different from the one known from RRMS and is characterized by premature signs of immune aging. This interpretation is further supported by our analysis of the CSF compartment of patients with PPMS vs patients with RRMS: Here, young patients with PPMS exhibited a pronounced immune cell infiltration of different immune cell subsets, with a significant decrease with age. This illustrates that especially in young patients with PPMS, there is a notable immune cell infiltration into the CSF as a clear indicator of inflammatory disease activity. Together, our data suggest that PPMS - particularly in younger patients-is indeed characterized by a distinct proinflammatory phenotype, which might explain the positive results of anti-inflammatory
DMTs, especially in young patients with PPMS. ${ }^{8,34}$ In a similar line, another study described that patients with PPMS with a higher T2 lesion load display in vitro increased rates of lymphocyte migration and enhanced IFN- $\gamma$ production compared with patients with PPMS with a lower lesion load. ${ }^{35}$ As different pathomechanisms are suggested to underlie this distinct proinflammatory phenotype, therapeutic approaches might indeed need distinct immunologic strategies compared with RRMS. Along this line, it is tempting to speculate that drugs, which target senescent cells (senolytics), could provide a suitable therapeutic strategy in PPMS. In animal models of neurodegenerative and other autoimmune diseases, targeted depletion of senescent cells by senolytics has already achieved success. $^{36-38}$

With respect to a potential clinical implication of our findings, we did not only observe an age-related upregulation of the costimulatory molecule CD226 (DNAM-1) on memory and EM CD8 T cells, but also identified a significant correlation between CD226 expression levels and the EDSS score only in young patients with MS, suggesting a link between the degree of premature immune aging and disease severity. CD226 is expressed constitutively on the majority of NK cells and $\mathrm{T}$ cells, mediating adhesion, costimulation, and cytotoxicity of immune cells. ${ }^{39,40}$ Initially, CD226 was described as a key molecule on proinflammatory Th1-differentiated cells and treatment with an $\alpha$-CD226 monoclonal antibody reduced the onset and severity of disease in experimental autoimmune encephalomyelitis (EAE), an animal model for MS. ${ }^{40}$ In the context of autoimmune diabetes, the knockout of CD226 led to a decreased disease severity in the nonobese diabetes mouse model. ${ }^{41}$ In humans, genetic variations of CD226 were linked to a higher susceptibility to develop MS and other autoimmune diseases. ${ }^{42}$ These findings, together with our data, imply that CD226 is regulated in an age-dependent manner and plays an important role in modulating autoimmunity. This concept is further supported by our observation of a correlation between sNfL levels and several other senescence-associated T-cell traits, and intriguingly, this was confined to young patients with MS, again supporting the idea that premature aging in MS might be associated with features of clinical disease manifestation. We are fully aware that caution is warranted due to limited sample size and lack of standardized long-term follow-up data from our patients and therefore suggest that these intriguing findings need to be corroborated in another independent cohort.

In conclusion, we identified that young patients with MS display signs of premature immune aging in the CD8 T-cell compartment, especially with respect to immunoregulatory molecules, whereas age-related changes in immune signatures in elderly patients with MS were comparable to those of HDs. This phenomenon of premature immune aging could be caused by chronic inflammation driving sustained alterations in immune-regulatory networks and ultimately cellular senescence, as it has been suggested in RA and SLE. 9,11,43 Further mechanistic studies are needed to determine the 
relationship between the premature aging phenotype (altered regulation of immunoregulatory molecules) and disease pathogenesis in MS.

\section{Acknowledgment}

The authors thank J. Meyer and M.L. Frankenberg (University Hospital Münster, Münster, Germany) for excellent technical assistance.

\section{Study Funding}

This study was funded by the Deutsche Multiple Sklerose Gesellschaft (DMSG) Landesverband Nordrhein-Westfalen (NRW) (to M.E. and M.P.), Innovative Medical Research (IMF) program of the Westfälische Wilhelms-University Münster (ES112007 to M.E. and M.P.), Interdisciplinary Center for Clinical Research (IZKF) Münster (K103/010/19 to L.K.), Deutsche Forschungsgemeinschaft (DFG) SFB TR128 (project A08 to L.K.), and Novartis (to L.K.).

\section{Disclosure}

M. Eschborn received speaker honoraria and travel support from Sanofi-Genzyme. She received research support from the Deutsche Multiple Sklerose Gesellschaft (DMSG) Landesverband Nordrhein-Westfalen (NRW) and the Innovative Medical Research (IMF) program of the University Münster. M. Pawlitzki received speaker honoraria and travel support from Novartis. He received research support from the DMSG Landesverband NRW and the IMF program of the University Münster. T. Wirth and C. Nelke report no disclosures. S. Pfeuffer received travel grants from Sanofi-Genzyme and Merck Serono, lecturing honoraria from Sanofi-Genzyme, Mylan Healthcare, and Biogen, and research support from Diamed, Merck Serono, and the DMSG Landesverband NRW. A. Schulte-Mecklenbeck received research and travel support from Novartis. L. Lohmann, L. Rolfes, K. Pape, and M. Eveslage report no disclosures. S. Bittner has received honoraria and compensation for travel from Biogen Idec, Merck Serono, Novartis, Sanofi-Genzyme, and Roche. C.C. Gross received speaker honoraria from Mylan, Bayer HealthCare, and SanofiGenzyme and travel/accommodation/meeting expenses from Bayer HealthCare, Biogen, Euroimmun, Novartis, and SanofiGenzyme. She also received research support from Biogen and Novartis. T. Ruck has received honoraria and consultation fee support from Celgene/BMS, Biogen, Roche, Sanofi-Aventis, Alexion, Novartis, and Teva and has received personal support from Merck Serono. H. Wiendl receives honoraria for acting as a member of scientific advisory boards for Biogen, Evgen, Genzyme, MedDay Pharmaceuticals, Merck Serono, Novartis, Roche Pharma AG, and Sanofi-Aventis as well as speaker honoraria and travel support from Alexion, Biogen, Cognomed, F. Hoffmann-La Roche Ltd., Gemeinnützige Hertie-Stiftung, Merck Serono, Novartis, Roche Pharma AG, Genzyme, Teva, and WebMD Global. Prof. Wiendl is acting as a paid consultant for Actelion, Biogen, IGES, Johnson \& Johnson, Novartis, Roche, Sanofi-Aventis, and the Swiss rheuma Society. His research is funded by the German Ministry for Education and Research (BMBF), Deutsche Forschungsgemeinschaft (DFG),

Else Kröner Fresenius Foundation, Fresenius Foundation, the European Union, Hertie Foundation, NRW Ministry of Education and Research, Interdisciplinary Center for Clinical Studies (IZKF) Muenster and Biogen, GlaxoSmithKline $\mathrm{GmbH}$, Roche Pharma AG, and Sanofi-Genzyme. S.G. Meuth received honoraria for lecturing and travel expenses for attending meetings from Almirall, Amicus Therapeutics Germany, Bayer HealthCare, Biogen Idec, Celgene, Diamed, Sanofi-Aventis, MedDay, Merck Serono, Novartis, Novo Nordisk, ONO Pharma, Roche, Chugai Pharma, QuintilesIMS, and Teva. His research is funded by the German Ministry for Education and Research (BMBF), Bundesinstitut für Risikobewertung (BfR), Deutsche Forschungsgemeinschaft (DFG), Else Kröner Fresenius Foundation, Gemeinsamer Bundesausschuss (G-BA), German Academic Exchange Service, Hertie Foundation, Interdisciplinary Center for Clinical Studies (IZKF) Muenster, German Foundation Neurology, and by Alexion, Almirall, Amicus Therapeutics Germany, Biogen Idec, Diamed, Fresenius Medical Care, Sanofi-Aventis, HERZ Burgdorf, Merck Serono, Novartis, ONO Pharma, Roche, and Teva. L. Klotz received compensation for serving on scientific advisory boards for Alexion, Genzyme, Janssen, Merck Serono, Novartis, and Roche. She received speaker honoraria and travel support from Bayer, Biogen, Genzyme, Grifols, Merck Serono, Novartis, Roche, Santhera, and Teva. She receives research support from the German Research Foundation, the IZKF Münster, IMF Münster, Biogen, Immunic AG, Novartis, and Merck Serono. Go to Neurology. org/NN for full disclosures.

\section{Publication History}

Received by Neurology: Neuroimmunology \& Neuroinflammation March 5, 2021. Accepted in final form August 30, 2021.

Appendix Authors

\begin{tabular}{|c|c|c|}
\hline Name & Location & Contribution \\
\hline $\begin{array}{l}\text { Melanie } \\
\text { Eschborn, PhD }\end{array}$ & $\begin{array}{l}\text { University Hospital } \\
\text { Münster, Germany }\end{array}$ & $\begin{array}{l}\text { Designed the study; data } \\
\text { acquisition; analyzed and } \\
\text { interpreted data; and wrote } \\
\text { the paper }\end{array}$ \\
\hline $\begin{array}{l}\text { Marc } \\
\text { Pawlitzki, MD }\end{array}$ & $\begin{array}{l}\text { University Hospital } \\
\text { Münster, Germany }\end{array}$ & $\begin{array}{l}\text { Designed the study; data } \\
\text { acquisition; analyzed and } \\
\text { interpreted data; and wrote } \\
\text { the paper }\end{array}$ \\
\hline $\begin{array}{l}\text { Timo Wirth, } \\
\text { PhD }\end{array}$ & $\begin{array}{l}\text { University Hospital } \\
\text { Münster, Germany }\end{array}$ & $\begin{array}{l}\text { Data acquisition; analyzed } \\
\text { and interpreted data; } \\
\text { performed statistical } \\
\text { analysis; and wrote the } \\
\text { paper }\end{array}$ \\
\hline $\begin{array}{l}\text { Christopher } \\
\text { Nelke, MD }\end{array}$ & $\begin{array}{l}\text { University Hospital } \\
\text { Münster, Germany }\end{array}$ & $\begin{array}{l}\text { Analyzed data and revised } \\
\text { the manuscript }\end{array}$ \\
\hline $\begin{array}{l}\text { Steffen } \\
\text { Pfeuffer, MD }\end{array}$ & $\begin{array}{l}\text { University Hospital, } \\
\text { Münster, Germany }\end{array}$ & $\begin{array}{l}\text { Analyzed data and revised } \\
\text { the manuscript }\end{array}$ \\
\hline $\begin{array}{l}\text { Andreas } \\
\text { Schulte- } \\
\text { Mecklenbeck, } \\
\text { PhD }\end{array}$ & $\begin{array}{l}\text { University Hospital, } \\
\text { Münster, Germany }\end{array}$ & $\begin{array}{l}\text { Analyzed data and revised } \\
\text { the manuscript }\end{array}$ \\
\hline
\end{tabular}


Appendix (continued)

\begin{tabular}{|c|c|c|}
\hline Name & Location & Contribution \\
\hline $\begin{array}{l}\text { Lisa } \\
\text { Lohmann, MD }\end{array}$ & $\begin{array}{l}\text { University Hospital, } \\
\text { Münster, Germany }\end{array}$ & $\begin{array}{l}\text { Analyzed data and revised } \\
\text { the manuscript }\end{array}$ \\
\hline $\begin{array}{l}\text { Leoni Rolfes, } \\
\text { MD }\end{array}$ & $\begin{array}{l}\text { University Hospital, } \\
\text { Münster, Germany }\end{array}$ & $\begin{array}{l}\text { Analyzed data and revised } \\
\text { the manuscript }\end{array}$ \\
\hline $\begin{array}{l}\text { Katrin Pape, } \\
\text { MD }\end{array}$ & $\begin{array}{l}\text { University Medical Center of } \\
\text { the Johannes Gutenberg } \\
\text { University, Mainz, Germany }\end{array}$ & $\begin{array}{l}\text { Data acquisition; analyzed } \\
\text { data; and revised the } \\
\text { manuscript }\end{array}$ \\
\hline $\begin{array}{l}\text { Maria } \\
\text { Eveslage, MSc }\end{array}$ & $\begin{array}{l}\text { University of Münster, } \\
\text { Germany }\end{array}$ & $\begin{array}{l}\text { Statistical data analysis and } \\
\text { revised the manuscript }\end{array}$ \\
\hline $\begin{array}{l}\text { Stefan } \\
\text { Bittner, MD }\end{array}$ & $\begin{array}{l}\text { University Medical Center of } \\
\text { the Johannes Gutenberg } \\
\text { University, Mainz, Germany }\end{array}$ & $\begin{array}{l}\text { Data acquisition; analyzed } \\
\text { data; and revised the } \\
\text { manuscript }\end{array}$ \\
\hline $\begin{array}{l}\text { Catharina C. } \\
\text { Gross, PhD }\end{array}$ & $\begin{array}{l}\text { University Hospital } \\
\text { Münster, Germany }\end{array}$ & $\begin{array}{l}\text { Analyzed data; supervised } \\
\text { CSF flow cytometry; and } \\
\text { revised the manuscript }\end{array}$ \\
\hline $\begin{array}{l}\text { Tobias Ruck, } \\
\text { MD }\end{array}$ & $\begin{array}{l}\text { University Hospital } \\
\text { Münster; present address: } \\
\text { University Hospital, } \\
\text { Münster, Germany }\end{array}$ & $\begin{array}{l}\text { Analyzed data and revised } \\
\text { the manuscript }\end{array}$ \\
\hline $\begin{array}{l}\text { Heinz Wiendl, } \\
\text { MD }\end{array}$ & $\begin{array}{l}\text { University Hospital, } \\
\text { Münster }\end{array}$ & $\begin{array}{l}\text { Analyzed and interpreted } \\
\text { data and revised the } \\
\text { manuscript }\end{array}$ \\
\hline $\begin{array}{l}\text { Sven G. } \\
\text { Meuth, MD, } \\
\text { PhD }\end{array}$ & $\begin{array}{l}\text { University Hospital } \\
\text { Münster; present address: } \\
\text { University Hospital, } \\
\text { Münster, Germany }\end{array}$ & $\begin{array}{l}\text { Designed and } \\
\text { conceptualized the study; } \\
\text { interpreted the data; and } \\
\text { edited the paper }\end{array}$ \\
\hline $\begin{array}{l}\text { Luisa Klotz, } \\
\text { MD }\end{array}$ & $\begin{array}{l}\text { University Hospital } \\
\text { Münster, Germany }\end{array}$ & $\begin{array}{l}\text { Designed and } \\
\text { conceptualized the study; } \\
\text { interpreted the data; and } \\
\text { edited the paper }\end{array}$ \\
\hline
\end{tabular}

\section{References}

1. Pawelec G. Age and immunity: What is "immunosenescence"? Exp Gerontol. 2018; 105:4-9.

2. Ray D, Yung R. Immune senescence, epigenetics and autoimmunity. Clin Immunol. 2018;196:59-63.

3. Vaughn CB, Jakimovski D, Kavak KS, et al. Epidemiology and treatment of multiple sclerosis in elderly populations. Nat Rev Neurol. 2019;15(6):329-342.

4. Weideman AM, Tapia-Maltos MA, Johnson K, Greenwood M, Bielekova B. Metaanalysis of the age-dependent efficacy of multiple sclerosis treatments. Front Neurol. 2017;8:577-612.

5. Sanai SA, Saini V, Benedict RH, et al. Aging and multiple sclerosis. Mult Scler. 2016; 22(6):717-725.

6. Mills EA, Mao-Draayer Y. Aging and lymphocyte changes by immunomodulatory therapies impact PML risk in multiple sclerosis patients. Mult Scler. 2018;24(8): 1014-1022.

7. Lublin F, Miller DH, Freedman MS, et al. Oral fingolimod in primary progressive multiple sclerosis (INFORMS): a phase 3, randomised, double-blind, placebocontrolled trial. Lancet. 2016;387(10023):1075-1084.

8. Hawker K, O'Connor P, Freedman MS, et al. Rituximab in patients with primary progressive multiple sclerosis: results of a randomized double-blind placebocontrolled multicenter trial. Ann Neurol. 2009;66(4):460-471.

9. Kalim H, Pratama MZ, Mahardini E, Winoto ES, Krisna PA, Handono K. Accelerated immune aging was correlated with lupus-associated brain fog in reproductive-age systemic lupus erythematosus patients. Int J Rheum Dis. 2020;23(5):620-626.

10. Petersen LE, Schuch JB, de Azeredo LA, et al. Characterization of senescence biomarkers in rheumatoid arthritis: relevance to disease progression. Clin Rheumatol. 2019;38(10):2909-2915.

11. Bauer ME. Accelerated immunosenescence in rheumatoid arthritis: impact on clinical progression. Immun Ageing. 2020;17:6-14.
12. Weyand CM, Goronzy JJ. Aging of the immune system. Mechanisms and therapeutic targets. Ann Am Thorac Soc. 2016;13(suppl 5):S422-S428.

13. Broux B, Markovic-Plese S, Stinissen P, Hellings N. Pathogenic features of CD4+CD28- T cells in immune disorders. Trends Mol Med. 2012;18(8):446-453.

14. Thewissen M, Somers V, Venken K, et al. Analyses of immunosenescent markers in patients with autoimmune disease. Clin Immunol. 2007;123(2):209-218.

15. Weng NP, Akbar AN, Goronzy J. CD28(-) T cells: their role in the age-associated decline of immune function. Trends Immunol. 2009;30(7):306-312.

16. Broux B, Mizee MR, Vanheusden M, et al. IL-15 amplifies the pathogenic properties of CD4+CD28- T cells in multiple sclerosis. J Immunol. 2015;194(5):2099-2109.

17. Nicaise AM, Wagstaff LJ, Willis CM, et al. Cellular senescence in progenitor cells contributes to diminished remyelination potential in progressive multiple sclerosis. Proc Natl Acad Sci USA. 2019;116(18):9030-9039.

18. Thompson AJ, Banwell BL, Barkhof F, et al. Diagnosis of multiple sclerosis: 2017 revisions of the McDonald criteria. Lancet Neurol. 2018;17(2):162-173.

19. Gross CC, Schulte-Mecklenbeck A, Madireddy L, et al. Classification of neurological diseases using multi-dimensional cerebrospinal fluid analysis. Brain 2021:awab147.

20. Posevitz-Fejfár A, Posevitz V, Gross CC, et al. Effects of blood transportation on human peripheral mononuclear cell yield, phenotype and function: implications for immune cell biobanking. Plos One. 2014;9(12):1-19.

21. R Core Team. R: A Language and Environment for Statistical Computing. 2020.

22. Jentsch-Ullrich K, Koenigsmann M, Mohren M, Franke A. Lymphocyte subsets' reference ranges in an age- and gender-balanced population of 100 healthy adults - a monocentric German study. Clin Immunol. 2005;116(2):192-197.

23. Qin L, Jing X, Qiu Z, et al. Aging of immune system: immune signature from peripheral blood lymphocyte subsets in 1068 healthy adults. Aging (Albany NY). 2016; 8(5):848-859.

24. Wertheimer AM, Bennett MS, Park B, et al. Aging and cytomegalovirus infection differentially and jointly affect distinct circulating $\mathrm{T}$ cell subsets in humans. J Immunol. 2014;192(5):2143-2155.

25. Goronzy JJ, Fang F, Cavanagh MM, Qi Q, Weyand CM. Naive T cell maintenance and function in human aging. I Immunol. 2015;194(9):4073-4080.

26. Pangrazzi L, Weinberger B. T cells, aging and senescence. Exp Gerontol. 2020;134: 110887.

27. Yang Z, Matteson EL, Goronzy JJ, Weyand CM. T-cell metabolism in autoimmune disease. Arthritis Res Ther. 2015;17:29.

28. Broux B, Pannemans K, Zhang X, et al. CX3CR1 drives cytotoxic CD4+CD28-T cells into the brain of multiple sclerosis patients. J Autoimmun. 2012;38(1):10-19.

29. Thewissen M, Linsen L, Somers V, Geusens P, Raus J, Stinissen P. Premature immunosenescence in rheumatoid arthritis and multiple sclerosis patients. Ann N Y Acad Sci. 2005; 1051:255-262.

30. Brenchley JM, Karandikar NJ, Betts MR, et al. Expression of CD57 defines replicative senescence and antigen-induced apoptotic death of CD8+ T cells. Blood. 2003; 101(7):2711-2720

31. Oost W, Talma N, Meilof JF, Laman JD. Targeting senescence to delay progression of multiple sclerosis. J Mol Med (Berl). 2018;96(11):1153-1166.

32. Louapre C, Collongues N, Stankoff B, et al. Clinical characteristics and outcomes in patients with coronavirus disease 2019 and multiple sclerosis. JAMA Neurol. 2020;77(9):1079-1088.

33. Hemmer B, Kerschensteiner M, Korn T. Role of the innate and adaptive immune responses in the course of multiple sclerosis. Lancet Neurol. 2015;14(4):406-419.

34. Montalban X, Hauser SL, Kappos L, et al. Ocrelizumab versus placebo in primary progressive multiple sclerosis. N Engl J Med. 2016;376(3):209-220.

35. Prat A, Pelletier D, Duquette P, Arnold DL, Antel JP. Heterogeneity of T-lymphocyte function in primary progressive multiple sclerosis: relation to magnetic resonance imaging lesion volume. Ann Neurol. 2000;47(2):234-237.

36. Chinta SJ, Woods G, Demaria M, et al. Cellular senescence is induced by the environmental neurotoxin paraquat and contributes to neuropathology linked to Parkinson's disease. Cell Rep. 2018;22(4):930-940.

37. Zhang P, Kishimoto Y, Grammatikakis I, et al. Senolytic therapy alleviates $A \beta$-associated oligodendrocyte progenitor cell senescence and cognitive deficits in an $\mathrm{Alz}$ heimer's disease model. Nat Neurosci. 2019;22(5):719-728.

38. Thompson PJ, Shah A, Ntranos V, Van Gool F, Atkinson M, Bhushan A. Targeted elimination of senescent beta cells prevents type 1 diabetes. Cell Metab. 2019;29(5): 1045-1060.e10.ko

39. Hafler JP, Maier LM, Cooper JD, et al. CD226 Gly307Ser association with multiple autoimmune diseases. Genes Immun. 2009;10(1):5-10.

40. Dardalhon V, Schubart AS, Reddy J, et al. CD226 is specifically expressed on the surface of Th1 cells and regulates their expansion and effector functions. J Immunol. 2005;175(3): 1558-1565.

41. Shapiro MR, Yeh WI, Longfield JR, et al. CD226 deletion reduces type 1 diabetes in the NOD mouse by impairing thymocyte development and peripheral $\mathrm{T}$ cell activation. Front Immunol. 2020;11:2180-2213.

42. Piédavent-Salomon M, Willing A, Engler JB, et al. Multiple sclerosis associated genetic variants of CD226 impair regulatory T cell function. Brain. 2015;138(Pt 11):3263-3274.

43. Tsai CY, Shen CY, Liao HT, et al. Molecular and cellular bases of immunosenescence, inflammation, and cardiovascular complications mimicking "inflammaging" in patients with systemic lupus erythematosus. Int J Mol Sci. 2019;20(16):3878 


\section{Neurology \\ Neuroimmunology \& Neuroinflammation}

\section{Evaluation of Age-Dependent Immune Signatures in Patients With Multiple Sclerosis}

Melanie Eschborn, Marc Pawlitzki, Timo Wirth, et al.

Neurol Neuroimmunol Neuroinflamm 2021;8;

DOI 10.1212/NXI.0000000000001094

This information is current as of October 19, 2021

\section{Updated Information \& Services}

References

Citations

Subspecialty Collections

Permissions \& Licensing

Reprints including high resolution figures, can be found at: http://nn.neurology.org/content/8/6/e1094.full.html

This article cites 41 articles, 6 of which you can access for free at: http://nn.neurology.org/content/8/6/e1094.full.html\#\#ref-list-1

This article has been cited by 1 HighWire-hosted articles: http://nn.neurology.org/content/8/6/e1094.full.html\#\#otherarticles

This article, along with others on similar topics, appears in the following collection(s):

Autoimmune diseases

http://nn.neurology.org//cgi/collection/autoimmune_diseases Multiple sclerosis

http://nn.neurology.org//cgi/collection/multiple_sclerosis

Information about reproducing this article in parts (figures,tables) or in its entirety can be found online at:

http://nn.neurology.org/misc/about.xhtml\#permissions

Information about ordering reprints can be found online: http://nn.neurology.org/misc/addir.xhtml\#reprintsus

Neurol Neuroimmunol Neuroinflamm is an official journal of the American Academy of Neurology.

Published since April 2014, it is an open-access, online-only, continuous publication journal. Copyright Copyright $\odot 2021$ The Author(s). Published by Wolters Kluwer Health, Inc. on behalf of the American Academy of Neurology.. All rights reserved. Online ISSN: 2332-7812.

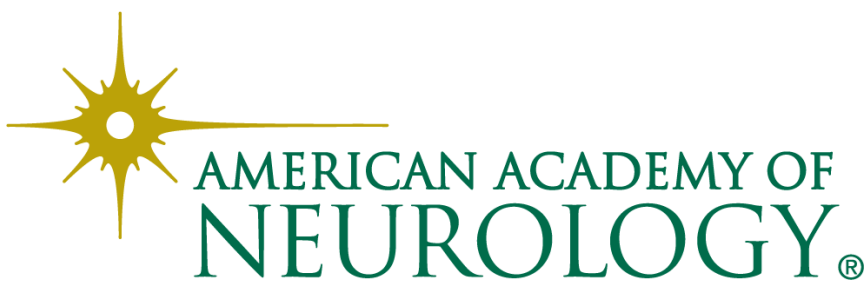

